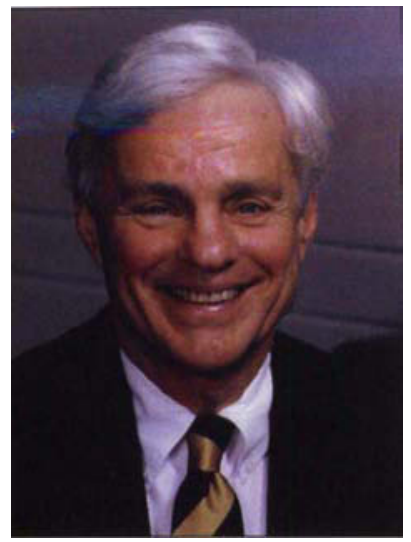

\title{
UC can build on land-grant idea
}

\author{
RICHARD C. ATKINSON \\ President \\ University of California
}

(As California Agriculture celebrates its 50th year of publication, we revisit the topics originally raised by former UC President Robert Gordon Sproul, in a commentary published in the first issue of December, 1946. -Ed.)

Ta $\mathrm{n}$ the inaugural issue of California Agriculture 50 years ago, President Robert Gordon Sproul cited a study showing that UC research had returned $\$ 28$ million to California farmers in 1931. By 1985, according to a UC Davis study, the annual flow of productivity benefits from UC agricultural research had climbed to $\$ 5.56$ billion. Such benefits far exceed annual costs of research, typically by a factor of 50 .

These figures reflect one of America's greatest success stories, the land-grant university. As California's land-grant institution, UC has a long and proud tradition of agricultural research and extension. UC's first agricultural experiment programs, created under the leadership of Eugene Hilgard on the Berkeley campus in the 1870s, later evolved into the California Agricultural Experiment Station at three sites - Berkeley, Davis, and Riverside.

Cooperative Extension (CE), the extension arm of the land-grant university, involves a unique three-way partnership between federal, state, and local governments. CE has brought land-grant university research directly to farmers and others who can use it, fueling social and economic development. Cooperative Extension is sometimes described as the "unseen University" because it does not operate from a single location, or from a cluster of buildings usually associated with a campus. Its CE specialists, affiliated with the campuses, and CE advisors, stationed in counties statewide, work with faculty to form a wonderfully productive research-extension continuum. UC scientists address problems identified by $C E$ advisors. CE advisors communicate the latest research results to the local community through non-degree education programs. CE specialists translate research results for practical use by advisors, perform applied research, and convey industry needs to campus researchers.

Sproul highlighted some of the benefits of this system in 1946 - the development of two new red kidney beans, the solution of the little-leaf riddle in deciduous fruit trees, and the development of pest management strategies for dairy and cattle operations. Today, 50 years later, UC research is still finding answers to problems. California strawberry yields, for instance, are the highest in the world, one result of the fact that $88 \%$ of California's strawberry acreage is planted to UC varieties. UC's Integrated Pest Management Project has reduced pesticide use statewide; from 1981 to 1985 , to mention just one example, almond growers cut pesticide use $24 \%$ using IPM techniques. And today agriculture accounts for almost $10 \%$ of the state's income and generates nearly $10 \%$ of all jobs in the state, thanks in no small part to UC research and extension.

Most CE efforts were originally concentrated in rural counties. Today, Cooperative Extension takes the University to a broad range of Californians up and down the state, from inner city children in Los Angeles and Oakland (see page 4) to growers both large and small in California's Central Valley. Low-income families receive nutrition education; foresters and watershed managers receive recent, research-based recommendations to conserve the state's unparalleled natural resources.

What we have learned in the past 120 years is that the land-grant model works. It has helped build an agricultural industry that is one of the largest and most productive sectors in the California economy.

As the largest and one of the most highly regarded of its kind in the world, UC's Division of Agriculture and Natural Resources has much to teach us about serving the people of California, whether the service we are rendering involves underrepresented students, participants in distance education programs, or university scientists forging new alliances with private industry.

The land-grant university was one of America's great contributions to higher education. That it has not just su vived but flourished is evidence of its remarkable produ tivity and enduring value. In an era of constrained resources and growing demand for knowledge in all its forms, the land-grant idea can only become more importan. as we seek to serve the people of California in the future as we have in the past. And California Agriculture will be a significant aspect of that service, as it has been for the past 50 years. 